\title{
A CASE OF ANOREXIA NERVOSA WITH NECROPSY FINDINGS AND A DISCUSSION OF SECONDARY HYPOPITUITARISM
}

\author{
BY \\ R. R. WILSON \\ From St. Mary's Hospital Medical School, London
}

(RECEIVED FOR PUBLICATION DECEMBER 21, 1953)

\begin{abstract}
Anorexia nervosa is seldom fatal, so there are few necropsy reports in the literature. The case reported here is of interest partly because it came to necropsy, and partly because the necropsy findings have a bearing on the question, much discussed in the literature, whether hypopituitarism may result from the inanition of anorexia nervosa.

It may seem unfortunate that so long a time has elapsed between the patient's death (1938) and the publication of this report. In those days hormonal assay was much less advanced than now, and the patient's unexpected death prevented much being done. Further, the war caused the matter to be set aside, not to be taken up again for more than a decade. However, so much of relevance has been learnt since those days that perhaps the case is even more interesting now than it was then.
\end{abstract}

\section{Case Report}

The patient, K.L., a woman of 26 , was admitted to Willesden General Hospital, under Dr. S. Leonard Simpson, on March 4, 1938, and died on March 8. She had previously been admitted to the London Hospital in 1935. The necropsy was performed by Dr. G. E. Harre.

In 1931, when K. L. was 19, she was discharged from work, as her employers were cutting down staff. She was very disappointed. Her periods suddenly stopped, and she began to lose weight. Her weight before her illness had been $120 \mathrm{lb}$. In 1935, when she was 23, she weighed $77 \mathrm{lb}$., and, in 1938, just before her death, $70 \mathrm{lb}$. Her own reports about her appetite are inconsistent.

She was very active even to the last; people stared to see someone so ill getting around so briskly. There had been partial loss of pubic and axillary hair.

She had chorea at the age of 7 , and acute rheumatism at 18. She left school at 14 and started work at 15 . She was happy at home and at work, but was not a good mixer. She led a sheltered life. At 18 she was good looking, rather plump, fond of music, and anxious to go to the Royal Academy of Dramatic Art, but her parents were too poor.
On her first admission, to the London Hospital in 1935, examination showed an extremely wasted girl. There was no abnormal pigmentation. The pulse was 60 , blood pressure $90 / 70-106 / 70 \mathrm{~mm}$. Hg. The heart, lungs, and central nervous system were normal. On pelvic examination the ovaries were not felt, and the uterus was reduced to the thickness of an index finger.

The blood count was within normal limits. The plasma protein was reduced to $5 \mathrm{~g} . / 100 \mathrm{ml}$, , serum calcium was $10.5 \mathrm{mg}$. $/ 100 \mathrm{ml}$. Two glucose tolerance curves were done. The first showed a fasting level of $80 \mathrm{mg}$. $100 \mathrm{ml}$., followed by $115 \mathrm{mg}$. at 30 minutes and $115 \mathrm{mg}$. again at 60 minutes. The second curve began at $77 \mathrm{mg} . / 100 \mathrm{ml}$., fasting level, followed by $220,190,220$, and $180 \mathrm{mg}$. at half-hour intervals. There was no glycosuria. Radiographs of the chest and long bones were normal. The B.M.R. on two occasions was $67 \%$ and $85 \%$ of normal.

On her second admission to hospital, to Willesden General Hospital in 1938, she was described by the house-surgeon as "skin and bones." Her skin was dry, scaly, and pallid, and puffy under the eyes and over the ankles. The scalp hair was brown, coarse, and dry; the eyebrows were well defined; pubic and axillary hair was present but somewhat scanty. Heart sounds were normal; the pulse was 60 , the blood pressure $104 / 62 \mathrm{~mm}$. Hg.

She was bright and alert. There was no indication on March 7, after three days in hospital, of any immediate danger to life. However, at 6.30 a.m. the next morning the nurse could not rouse her; at 8 a.m. it was realized that she was in coma. She died soon after. Clinically it seemed that she was in hypoglycaemic coma. (A sample of blood taken at necropsy contained no sugar.)

Diagnosis.-Clinically, there seems no doubt that the diagnosis of anorexia nervosa was accurate, and the case rather typical.

In spite of considerable emaciation, she manifested great activity and restlessness, in contrast to the apathy and inertia of Simmonds's disease. The growth of fine down on the face was in keeping with the diagnosis of anorexia nervosa ; in this and other states of inanition, including famine, such downy hair may 
grow over the whole body. It is not met with in Simmonds's disease.

Complete or almost complete loss of pubic and axillary hair is usual in Simmonds's disease and invariable if the pituitary insufficiency is severe. In contrast, persistence of pubic and axillary hair is characteristic of anorexia nervosa, even of severe degree.

\section{Post-mortem Findings}

External Appearances.-The body was that of an extremely emaciated young woman. The axillary hair was sparse, as was that over the mons pubis, but there was more on the vulva. The scalp hair was thin. There was some soft hair over the angle of the jaw.

Cardiovascular System.-The myocardium was brownish. The right ventricle was $0.3 \mathrm{~cm}$. thick, the left ventricle $0.9 \mathrm{~cm}$. The mitral cusps were pale, and showed bulbous thickenings. The heart as a whole was very small.

Respiratory System.-The lungs were somewhat brown, and dry on cutting ; there was fine emphysema.

Alimentary System.-The lingual and pharyngeal tonsils were very small. The stomach contained thick, bile-stained chyme and much mucus. The gut generally was contracted. The liver was small ( $453 \mathrm{~g}$.), its colour markedly brown, its pattern very small. The gall bladder and bile ducts were normal. The pancreas was small (41.5 g.) and of a deep yellowish-brown.

Haemopoietic and Endocrine System.-The lymph glands generally were small, save for some calcified mesenteric glands. The spleen weighed only $38.7 \mathrm{~g}$.; it was moderately firm, with a finely wrink!ed capsule. On section the fibrous tissue was conspicuous, the Malpighian bodies extremely small. The thymus had apparently atrophied completely. The thyroid was small and pale. The suprarenals, weighing together $9.1 \mathrm{~g}$., were firm and reddish-yellow; on section, lipoid and pigment zones could be seen, though the latter was thin. The medulla was easily discerned. The pituitary appeared normal ; it weighed $0.7 \mathrm{~g}$. and measured $1.25 \times 0.9 \times 0.6 \mathrm{~cm}$.

Urinary System.-The kidneys were small and firm ; the right kidney weighed $71 \mathrm{~g}$., the left $63.5 \mathrm{~g}$. The capsules stripped readily, and the pattern was good.

Female Genitalia.-The uterus was small, being $4.7 \mathrm{~cm}$. long, of which the cervix made up $2.2 \mathrm{~cm}$.; the endometrium was smooth. The ovaries were small and very firm, with cut surfaces almost devoid of pattern.
Nervous System.-The brain $(1,335$ g.) appeared normal externally.

Chemical Analysis.-A specimen of blood was obtained about three and a half hours after death and taken immediately for estimation of sugar. No sugar was found. (Three control tests were done on other cases, the samples being taken six, nine, and 17 hours after death; the blood sugar was 36,122 , and $33 \mathrm{mg}$. per $100 \mathrm{ml}$. respectively). The non-protein nitrogen was $64 \mathrm{mg}$. per $100 \mathrm{ml}$, the total protein $5.16 \mathrm{mg}$., and the blood chloride $383 \mathrm{mg}$. per $100 \mathrm{ml}$.

\section{Histological Findings}

Pituitary.-It was obvious from haematoxylin and eosin sections that the gland was abnormal. Nearly all cells showed faint eosinophilia ; lightly staining granules were visible with the $1 / 12$ in. objective. There was no scarring.

The gland was treated on the lines indicated by Crooke and Russell (1935). In view of the histological abnormality of this pituitary every section was stained in exact parallel with a normal control (Figs. 1 and 2).

The glandular cells fell into four groups. One group was of cells containing fuchsinophil

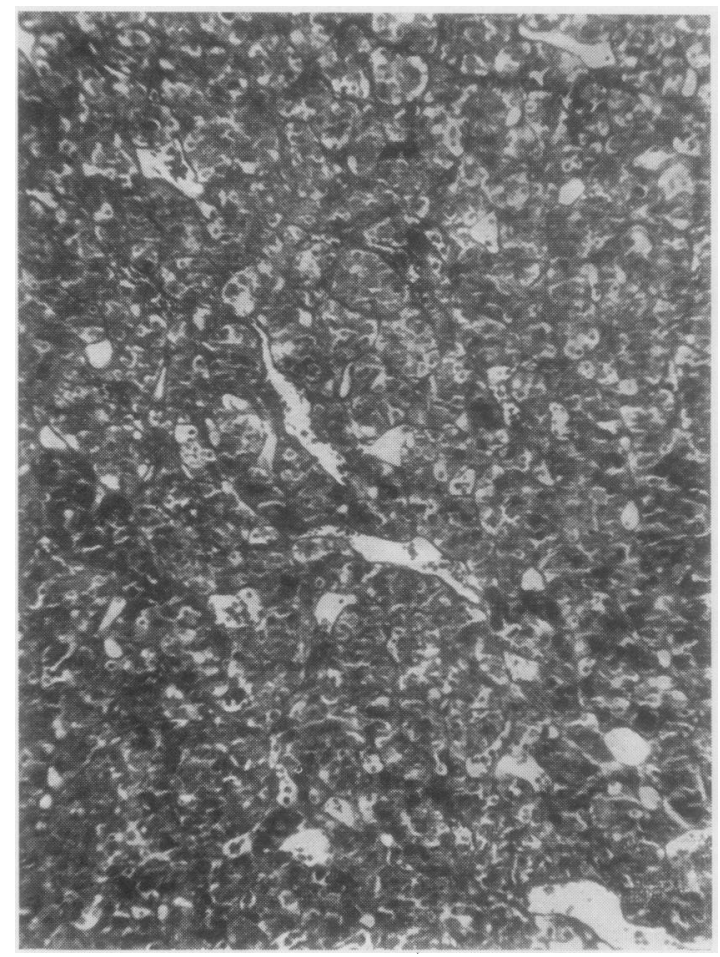

FIG. 1.-A typical low-power field of the pituitary of this case, stained by acid fuchsin-aniline blue-orange $G . \times 95$. 


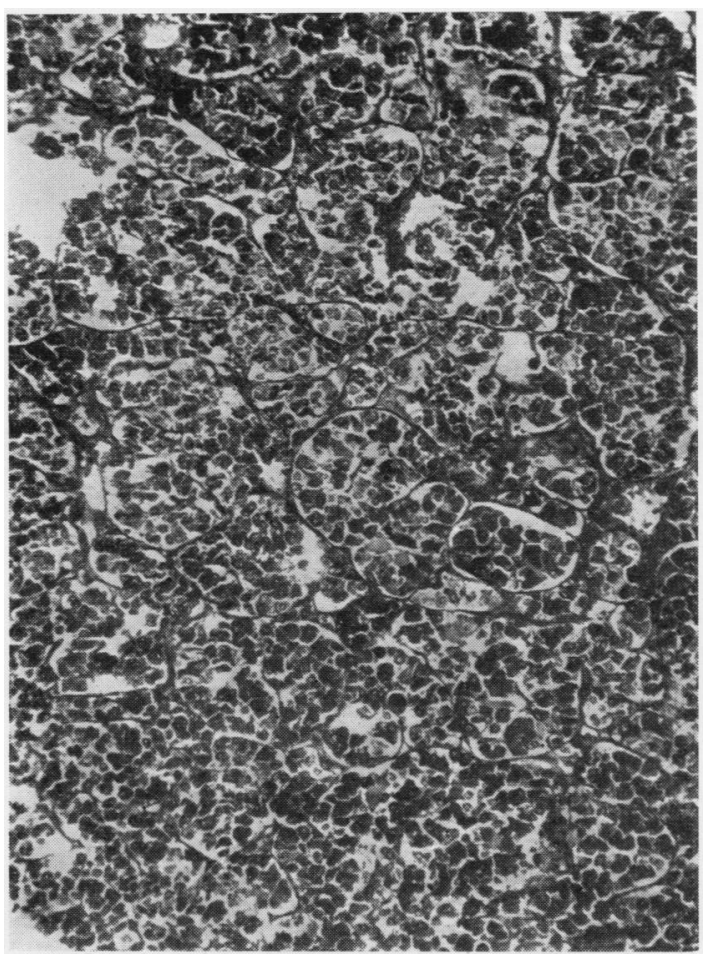

FIG. 2.-A typical low-power field of the normal control stained in parallel with that shown in Fig. $1 . \times 95$.

granules. The granules were in most cases very scanty and in only a few cells did they fill the cytoplasm in the way seen in normal acidophil cells. A second group was of cells having cytoplasmic granules staining with orange G. Here again the granules were generally scanty. A third group was of cells containing granules staining with aniline blue, as do the basophil cells in the normal pituitary. Most of these were filled with granules. The fourth group was of cells containing no granules, or occasionally granules not staining at all. Most of these cells had scanty cytoplasm ; in many cases they appeared as "groups of nuclei embedded in a common cytoplasm," to quote the description given to some of the normal chromophobe cells by Bailey (1932).

The percentages of the various cell types were:

\begin{tabular}{cccccc}
$\begin{array}{c}\text { Fuchsinophil (acidophil) cells } \\
\text { (apparently normal }\end{array}$ & $\ldots$ & $\ldots$ & 15.3 \\
included in above) & & $\ldots$ & $\ldots$ & $(1.26)$ \\
$\begin{array}{c}\text { Orange G cells } \ldots \\
\text { Basophil cells } \ldots\end{array}$ & $\ldots$ & $\ldots$ & $\ldots$ & 42.5 \\
$\begin{array}{c}\text { Basophil } \\
\text { Chromophobe cells }\end{array}$ & $\ldots$ & $\ldots$ & $\ldots$ & 4.64 \\
& $\ldots$ & $\ldots$ & $\ldots$ & 37.4 \\
\hline
\end{tabular}

Sections were also treated by the periodic-acidSchiff (P.A.S.) technique described by Pearse (1949) for the localization of gonadotrophic hormone. A count was done of P.A.S.-positive cells in a selected strip right across one of the sections, and also of basophil cells in the corresponding part of the next section in the series, stained by the acid fuchsin-aniline blue-orange $G$ method. It was found that the basophil cells were P.A.S.positive but that many P.A.S.-positive cells were not shown up as basophil cells by the latter method. This conforms with Pearse's findings. (For 135 basophil cells in the one section there were 459 P.A.S.-positive cells in the other.)

Adrenals. - The cortex was generally narrow. In one section the thickness was $0.6 \mathrm{~mm}$. (mean of measurements at 15 places), in another $0.75 \mathrm{~mm}$. (mean of 24 measurements). The zona glomerulosa and zona reticularis in particular were very narrow, their component cells often atrophic, with pyknotic nuclei. In some places these zones had almost or altogether disappeared; where this was the case the zona fasciculata was especially thin, though this zone was everywhere the least atrophic of the three. The capsule of the gland was generally thicker than normal, and most thickened where the cortex was most thinned. Collagen fibres were present in excess among the cells of the zona reticularis, and pigment in these cells was scanty. The medulla was normal.

Ovaries.-The cortex was very thin. There were a few old corpora alba. A small number of primordial follicles were found ; no follicle showed the slightest degree of maturation.

Myometrium.-There was great atrophy of the muscle fibres.

Liver.-The lobules and the cells were small. A large amount of iron-containing pigment was present, some in the liver cells, some in the Kuppfer cells. There was no cirrhosis.

Spleen.-The most striking change was the great amount of iron-containing pigment, some of which was loose in the connective tissue of the sinusoidal walls, some in histiocyte-like cells scattered through the pulp. The sinusoids were moderately dilated and were lined by low epithelium-like cells : there was increased connective tissue in their walls. The Malpighian bodies were very small.

Pancreas.-The islets appeared small and scanty. Most of the islet cells were small, but otherwise appeared normal.

The exocrine cells appeared normal apart from being rather small. 
Heart.-The general picture was that of brown atrophy.

Stomach.-The mucosa was thin but histologically normal. The lymphoid follicles were very scanty and small.

Tonsils and Lymph Glands.-The amount of lymphoid tissue was remarkably small ; only a few of the very small follicles had germ centres, and these too were very small. The sinusoids were dilated.

Kidneys.-There was much congestion. The glomeruli and tubular epithelial cells appeared smaller than normal. The kidneys were otherwise normal.

\section{Discussion}

Conflict of Views.-In the literature, much discussion is devoted to the relationship, if there is one, between anorexia nervosa and Simmonds's disease. Many conflicting statements are made, many conflicting opinions expressed. Some say "there is no reason to believe that pituitary deficiency exists in anorexia nervosa" (McCullagh and Tupper, 1940). Others-more numeroussay that hypopituitarism may occur in anorexia nervosa. Of these, some consider the hypopituitarism the result of inanition (Decourt and Michard, 1949 ; Stephens, 1941 ; Loeper and Sainton, 1937) ; others regard the hypopituitarism as of psychological or emotional origin (Sheldon, 1937 ; Spence, 1939 ; Querido, 1949 ; Bartels, 1946) ; others, such as Schermann (1947), hold that the anorexia and other psychological changes and the endocrine manifestations are due to disturbance of the pituitary-diencephalic region by factors not fully understood. Sheldon (1939) suggested that " the mechanism adjusting the body to a lowered intake of food ... acts ... by a general inhibition of anterior pituitary activity." Hubble (1952) says that malnutrition can affect the formation of anterior pituitary hormones, and psychogenic depression also occurs.

Confusion of Anorexia Nervosa with Simmonds's Disease.-Some writers use expressions which may well have caused confusion. Cornil and Schachter (1939-41) say that "most cases of anorexia nervosa are really more or less attenuated forms of Simmonds's disease." Selye (1947) states that in anorexia nervosa "the fundamental cause of the symptoms is a secondary hypopituitarism." Decourt (1942) remarks that anorexia nervosa and Simmonds's disease differ only in their original causes. Repetto, Ianni, and Benzecry (1947) report a case as changing from anorexia nervosa

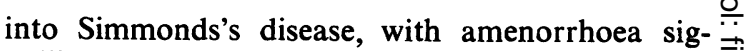
nalling the change. Pagniez (1939) thought that anorexia nervosa and Simmonds's disease were dis- $\overline{0}$ tinct, but that there occurred intermediary forms $\frac{\bar{\sigma}}{\underline{\sigma}}$ of doubtful nature.

It is proper to emphasize that anorexia nervosa $\stackrel{\nabla}{\varnothing}$ is a disease of psychological origin, while Simmonds's disease is the result of destruction of the

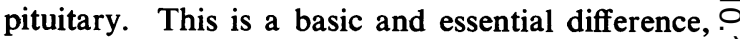
which might be expected to settle the problem, if $\vec{\omega}$ only at necropsy. Although Escamilla and Lisser $\stackrel{\circ}{\circ}$ (1942), in an exhaustive analysis of the literature on Simmonds's disease, found themselves obliged $v$ to distinguish two small exceptional groups of $i$ cases (one with pituitary destruction but no $\vec{\omega}$ typical clinical picture, the other with the typical $\vec{\circ}$ clinical picture but an apparently normal pituitary $\frac{}{3}$ at necropsy), many authors seem to think that as $\vec{z}$ a rule there should be no confusion clinically or pathologically. It seems wrong to say, for example, that " anorexia nervosa is an attenuated $\stackrel{\oplus}{O}$ form of Simmonds's disease"; and it seems $\perp$ advisable that such expressions as "functional Simmonds's disease" be avoided. (Gull's original name of "hysteric apepsia" (1868) is nearer the truth ; nearer even than "anorexia nervosa," for, in his detailed description (1874), Gull said he $\mathbb{\perp}$ thought anorexia nervosa was due to " a failure of $\underset{\vec{P}}{\Rightarrow}$ the powers of the gastric branches of the pneumo- $\frac{0}{3}$ gastric nerve.")

Can Inanition Cause Hypopituitarism ?-There? remains the question of whether or not hypo- $\overline{0}$ pituitarism may arise in the course of anorexia? nervosa as a result of inanition. It is certain that such hypopituitarism, if it does occur, is reversible, for most patients recover more or less completely $\frac{0}{3}$ when they resume a normal diet after simple per- 0 suasion or other forms of psychotherapy (Bond, 1949 ; Brosin, 1941 ; Clow, 1932 ; Hurst, 1939 ; $\frac{\mathrm{O}}{\mathrm{O}}$ Lorand, 1943 ; Palmer, 1939 ; Pardee, 1941 ; Parker, 1940 ; Roch and Monnier, 1941 ; Venables, $N$ 1930).

Evidence from Inanition in Man.-Berkman $\mathcal{W ~}^{-}$ (1930, 1948), studying the Mayo Clinic's cases from 1917 onwards, said in the later paper that the laboratory tests showed severe insufficiency of $\frac{\text { C }}{0}$ the anterior pituitary function. Querido (1949) took a similar view on the basis of the hormone analyses he had gathered from the literature. Davis (1939) found that endocrine therapy was ineffective; but that does not prove there was no $\frac{\mathbb{D}}{0}$ endocrine hypofunction.

The evidence from human starvation is conflicting. Harris (1919) quotes Rubinato (1914) as say- $\bigcirc$ ing that in pellagra the chromophil cells of the 
pituitary are atrophied and crowded together (by which he might have meant they were degranulated), but he also quotes Rossi (1913) to the effect that the pituitary in pellagra is normal. Lhermitte (1944), studying elderly people with deficiency diseases who died with spontaneous hypoglycaemia, found a reduction of the glandular cells of the anterior pituitary ; most of the remaining cells were chromophobes, acidophils and basophils being found only here and there ; bands of dense fibrosis traversed the anterior lobe. Nicolaief (quoted by Loeper and Sainton, 1937, unfortunately without a full reference) found in victims of the Kiev famine that the eosinophils were reduced in number. Two fatal cases of anorexia nervosa were found to have normal pituitaries (Brosin and Apfelbach, 1941 ; Osgood, 1938) ; Decourt and Michard (1949) stated that in fatal anorexia nervosa the pituitary may be normal. Cameron (1947) held the same view.

The Pituitary in Anorexia Nervosa.-It is of interest to review the pituitary changes found in fatal cases of anorexia nervosa. If one may assume that (1) the few authors who have made two reports have not reported the same case twice, (2) all the cases are truly cases of anorexia nervosa-and most of them are, (3) following Sheldon (who said (1939) that Kylin's monograph on Simmonds's disease is "really one of the more important papers on anorexia nervosa"), all Kylin's cases $(1935,1937)$ are cases of anorexia nervosa, then there have been collected about 440 cases of that condition, in the course of this study. Of these 29 died, and 22 came to necropsy. There is no mention of the pituitary in 14 of these reports, but in the other eight the histology is given. It is not easy to know what to make of them, partly because technical methods are not given and technique plays a large part in the examination of a pituitary. With such reservations in mind the glandular cells of the anterior pituitary can be described as definitely abnormal in only three of the eight cases: Richardson's case, Kylin's third case (Karin H.), and this case (K. L.).

The Other Endocrines in Human Inanition.No definite conclusion emerges from the findings in other endocrine glands under pituitary influence. Packard and Wechsler (1934) observed both hypertrophy and degeneration in the adrenals of four people dying of chronic malnutrition. Elliott (1914) reported two fatal cases of anorexia nervosa ; in one the adrenals were "crammed with lipoid," in the other normal. McCullagh and Tupper (1940) found normal adrenals in a fatal case of anorexia nervosa. Nicolaief (Loeper and Sainton, 1937) reported atrophy of thyroid and adrenals, and lack of follicle ripening in the ovaries. As to the gonads and their function, it is sometimes thought (Repetto et al., 1947) that amenorrhoea is a sign of hypopituitarism, but the amenorrhoea often comes on early in the disease (Hubble, 1952, and other writers); in the present case it was almost the first event. Sydenham (1946), telling of women prisoners in Japanese hands in Hong Kong in the last war, says that amenorrhoea was the rule during the first few months, but that menstruation was re-established and maintained during three years of semistarvation. Temporary amenorrhoea following an emotional upset or change of surroundings is very common among adolescents.

Evidence from Inanition in Animals. - A great amount of experimental work on animals has been done, with some bearing on this problem. Degranulation and atrophy of chromophil cells in the pituitary was observed in rats deficient in vitamin E (Barrie, 1937) and in starvation (Jackson, 1917; Werner, 1939; Mulinos and Pomerantz, 1940). Werner (1939) observed loss of pituitary potency in starved rats ; Mulinos, Pomerantz, Sme'ser, and Kurzrok (1939) found that pituitary gonadotrophic hormone abolished inanition anoestrus in rats. Mulinos and Pomerantz (1940) studied malnutrition in 300 albino rats. The changes in the pituitary have already been mentioned; in the adrenal, thyroid, spleen, thymus, liver, and gonads the changes resembled those that follow hypophysectomy. Mulinos and Pomerantz found this so striking that they called malnutrition "pseudo-hypophysectomy." D'Angelo, Gordon, and Charipper (1948) found the adrenals hypertrophied in starved guinea-pigs, and Lockwood and Hartman (1933) found hypertrophy in deficiency of vitamin $C$ and $B_{1}$, but atrophy in vitamin A deficiency. Rat adrenals were hypertrophic in vitamin $\mathbf{B}_{2}$ deficiency (Findlay, 1928).

Conclusion.-The many contradictions between these reports are less surprising when one remembers that different species were being observed, and that malnutrition varied in degree, in nature, and in duration. However, one cannot ignore the positive reports of loss of granules, etc., in the glandular cells of the pituitary in malnutrition, and of hypoplasia of adrenals, gonads, and thyroid, which suggest a diminution of the corresponding pituitary hormones. In the present case the pituitary was remarkable for its lack of nor- 
mally granulated cells, and other organs showed many features found in definite hypopituitarism. This can be said, because Sheehan and Summers (1949) have exhaustively analysed the gross and microscopic findings in a large number of reported cases of definite Simmonds's disease. What they have shown to be usual in Simmonds's disease is closely matched in this case of anorexia nervosa ; the parallel is close or exact in the ovaries, uterus, adrenals, liver, spleen, lymphoid tissue, kidneys, and thyroid (there is inadvertently no microscopic material from the thyroid, but macroscopically it was "small and pale").

It appears reasonable to conclude, from all the evidence, that in some cases of severe anorexia nervosa the inanition can cause hypopituitarism. It is perhaps not surprising, in view of the complexity of the matter and its many seeming contradictions, that no more clear-cut statement can at present be made.

\section{Summary}

A fatal case of anorexia nervosa is reported, with gross and microscopic necropsy findings. The adrenals, gonads, thyroid, and other organs showed atrophic changes comparable to those found in Simmonds's disease.

The pituitary was very cellular. Basophil and chromophobe cells were present in normal proportions, but nearly all other cells were sparsely granulated and normal acidophils were very scanty. There are some reports in the literature of similar pituitary abnormalities in human and animal malnutrition.

Anorexia nervosa and Simmonds's disease are quite distinct from each other, but may be confused because of clinical similarities. The similarities have given rise to the idea that hypopituitarism due to inanition may result from anorexia nervosa. The findings in this case, and in man and animals as reported in the literature, are thought to uphold the conception that this happens in some cases.

I wish to acknowledge my indebtedness to Dr. S. Leonard Simpson, consultant endocrinologist to St. Mary's Hospital, who has not only given me the use of the clinical material but also made many helpful suggestions and criticisms. Thanks are due also to the London Hospital, who gave Dr. Simpson access to their records. Dr. G. E. Harre is also thanked for doing the necropsy and preliminary histological work while she was pathologist at Willesden General Hospital. Dr. C. L. Foster, reader in biology at St. Mary's Hospital Medical School, gave helpful advice. Dr. E. Kawerau, of the Chemical Pathology Laboratory at St. Mary's Hospital, kindly did the sugar estimations on the control post-mortem blood specimens. My chief. Professor W. D. Newcomb, has given me much help and encouragement.

\section{REFERENCES}

I. References to articles mentioned in the text

Bailey, P. (1932). In Special Cytology, 2nd ed., Vol. 2, p. 779, ed. Cowdry, E. V. Hoeber, New York.

Barrie, M. M. O. (1937). Lancet, 2, 251.

Bartels, E. D. (1946). Acta med. scand., 124, 185.

Berkman, J. M. (1930). Amer. J. med. Sci., 180, 411

(1948). Postgrad. Med., 3, 237.

Bond, D. D. (1949). Rocky Min med. J., 46, 1012.

Brosin, H. W. (1941). J. clin. Endocr., 1, 269.

- and Apfelbach, C. (1941). Ibid., 1, 272.

Cameron, A. T. (1947). Recent Advances in Endocrinology, 6th ed., pp. 364-8. London.

Clow, F. E. (1932). New Engl. med. J., 207, 613.

Cornil, L., and Schachter, M. (1939-41). Encéphale, 34, 371.

Crooke, A. C., and Russell, Dorothy S. (1935). J. Path. Bact., 40, 255.

D'Angelo, S. A., Gordon, A. S., and Charipper, H. A. (1948). Endocrinology, 42, 399.

Davis, Helen P. (1939). Ibid., 25, 991.

Decourt, J. (1942). Presse méd., 50, 629.

Decourt, J. (1942). J. (1949). Sem. Hôp. Paris, 25, 3343.

Elliott, T. R. (1914). Quart. J. Med., 8, 47.

Escamilla, R. F., and Lisser, H. (1942). J. clin. Endocr., 2, 65.

Findlay, G. M. (1928). J. Path. Bact., 31, 353.

Gull, W. (1868). Lancet, 2, 171.

- (1874). Trans. clin. Soc. Lond., 7, 22.

Harris, H. F. (1919). Pellagra, pp. 164, 171. Macmillan, New York.

Hubble, D. (1952). Lancet, 1, 1123

Hurst, A. (1939). Proc. roy. Soc. Med., 32, 744

Jackson, C. M. (1917). Amer. J. Anat., 21, 321.

Kylin, E. (1935). Ergebn. inn. Med. Kinderheilk, 49, 1.

- (1937). Dtsch. Arch. klin. Med., 180, 115.

Lhermitte, J. (1944). Rev. méd. fran ., 25, 62.

Lockwood, J. E. and Hartman, F. A (1933). Endocrinology, 17, 501.

Loeper. M. and Sainton, J. B. (1937). Progr. méd., Paris, 64, 1408.

Lorand, S. (1943). Psychosom. Med., 5, 282.

Mulinos, M. G., and Pomerantz, L. (1940). J. Nutr., 19, 493. Smelser, Jane, and Kurzrok, R. (1939). Proc. Soc. exp. Biol., N.Y., 40, 79.

McCullagh, E. P., and Tupper, W. R. (1940). Ann. intern. Med., 14,817 .

Nicolaief. Quoted by Loeper and Sainton.

Osgood, E. E. (1938). Endocrinology, 23, 656.

Packard, M., and Wechsler, H. F. (1934). Arch. intern. Med., 54, 18.

Pagniez, P. (1939). Presse méd., 47, 668.

Palmer, H. A. (1939). Lancet, 1, 269.

Pardee, I. (1941). Med. Clin. N. Amer., 25, 755.

Parker, H. L. (1940). Irish J. med. Sci., Sixth Series, No. 175, p. 289.

Pearse, A. G. E. (1949). J. Path. Bact., 61, 195.

Pearse, A. G. E. (1949). J. Path. Bact., 61, 195.
Querido, A. (1949). Ned. T. Geneesk., 92, 660.

Repetto, R., Ianni, J., and Benzecry, I. (1947). Pren. méd. argent., 34, 362 .

Richardson, H. B. (1939). Arch. intern. Med., 63, 1.

Roch, M., and Monnier, M. (1941). Rev. mid. Suisse rom., 61, 321.

Rossi, O. (1913). J. Psychol. Neurol., Lpz., 20, 1. (Quoted by Harris.)

Rubinato G. (1914), Riv. crit. Clin. med., 15, 65. (Quoted by

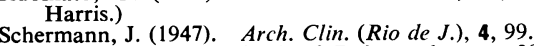

Selye, H. (1947). Textbook of Endocrinology, p. 283. Acta endocrinologica, Montreal.

Sheehan, H. L., and Summers, V. K. (1949). Quart. J. Med., 18, 319. Sheldon, J. H. (1937). Lancet, 1, 369.

Sheldon, (1939). Proc. roy. Soc. Med., 32, 738.

Spence, A. W. (1939). Ibid., 32, 741.

Stephens, D. J. (1941). J. clin. Endocr., 1, 257

Sydenham, A. (1946). Brit. med. J., 2, 159.

Venables, J. F. (1930). Clin. J., 59, 544.

Werner, S. C. (1939). Proc. Soc. exp. Biol., N.Y., 41, 101.

II. References to case reports drawn upon but not specified in the text

Bruckner, W. J., Wies, C. H., and Lavietes, P. H. (1938). Amer. J. med. Sci., 196, 663.

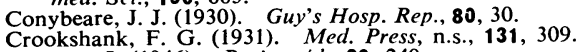

Crookshank, F. G. (1931). Med. Press,

Evans, J. C. G. (1939). Lancet, 1, 268.

Farquharson, R. F. (1941). Illinois med. J., 80, 193.

Farquharson, R. F. (1941) (1938). J. Amer. med. Ass., 111, 1085.

Langdon-Brown,W. (1931). Med. Press, n.s., 131, 308.

Magendantz, H., and Proger, S. (1940). J. Amer. med. Ass., 114, 1973 .

Marshall, C. F. (1895). Lancet, 1, 149.

Reiss, M. (1943). J. ment. Sci., 89, 270

Rohmer, M. P., and Jung, C. (1938), Bull. Soc. Pédiat. Paris, 36, 524.

Ryle, J. A. (1936). Lancet, 2, 893 .

Stephens, L. (1895). Ibid., 1, 31.

Stévenin, H., and Gaube, R. (1938). Monde mid., 48, 489.

White, W. G., and Moehlig, R.C. (1950). J. Mich. med. Soc., 49, 665. 